\title{
Isolation and identification of Candida spp. from immunocompromised patients
}

\author{
Anas Salama Sayed Hemaid ${ }^{1 *} \mathbb{B}$, Mohamed Mahmoud Effat Abdelghany ${ }^{2}$ and Tarek Mohamed Abdelghany ${ }^{1}$
}

\begin{abstract}
Background: Candida species is considered one of the normal inhabitant commensal microbiota of the human body. However, it can also act as an opportunistic pathogen especially in hospitals (nosocomial infection) and among immunocompromised patients. The accurate, precise, rapid and reliable identification of Candida to the species level is of great importance for control and management of candidiasis.

Results: One hundred and eighteen different samples were collected (59 urine samples, 39 oral swabs, 5 vaginal swabs and 15 skin swabs) from immunocompromised patients (diabetics - pregnant women — patients underwent organ transplantation - cancer patients - burned and wounded patients) for probable existence of Candida species. Eighty-six out of 118 (72.8\%) samples were typed macroscopically and microscopically and found to be Candida species. Upon streaking 86 Candida isolates on CHROMagar plates separately, 48 isolates gave green colonies, 25 isolates gave rose colonies, 10 isolates gave white colonies, 2 isolates gave pale coloured colonies and 1 isolate gave blue colonies. Forty-eight out of 86 isolates showed positive Germ tube test. API $20 \mathrm{C}$ assay was performed on some isolates with different coloured colonies, the results were similar to those of CHROMagar. Upon performing PCR assay on 14 isolates using ITS1 and ITS4 primers, 8 out of 14 PCR product bands appeared between 510 and 535 bp and this was difficult to differentiate among them (C. albicans, C. tropicalis, C. krusei and C. parapsilosis). Five out of 14 PCR products were found at $871 \mathrm{bp} \mathrm{(C.} \mathrm{glabrata)} \mathrm{and} \mathrm{the} \mathrm{last} \mathrm{one} \mathrm{is} \mathrm{negative} \mathrm{control} \mathrm{with} \mathrm{no} \mathrm{band} \mathrm{appeared.} \mathrm{Further} \mathrm{molecular}$ studies should be recommended to fully differentiate among Candida species especially those with very close bands. Antifungal activity (expressed by inhibitory zone) of zinc oxide nanoparticles in comparison with some commercially available antifungals (nystatin and Voriconazole) was carried upon the obtained Candida isolates. Zinc oxide nanoparticles with $100 \mu \mathrm{g} /$ disc showed 9, 26, 40, $42 \mathrm{~mm}$ inhibitory zones for C. tropicalis, C. glabrata, C. albicans and C. parapsilosis, respectively. However, zinc oxide only showed no antifungal activity against $C$. krusei.
\end{abstract}

Conclusions: A sheet of identification profile for Candida should include morphotyping, biotyping and genotyping to reach a rapid, reliable and accurate diagnosis. Candida species causes a myriad of infections causing non-invasive, mucocutaneous infections and severe systemic and deep-seated disease. Repress of Candida growth by ZnONPs provides an insight towards their therapeutic application for the prevention of Candida-associated infections. Further studies on the antifungal effect of nanoparticles combined with commercially available antifungal medicines maybe recommended.

Keywords: Immunocompromised, Germ tube, Chlamydospores, CHROMagar, Candida species, API 20C, PCR, Nanoparticles

*Correspondence: anas_hemaid@yahoo.com

${ }^{1}$ Botany and Microbiology, Faculty of Science, Al-Azhar University, Cairo, Egypt

Full list of author information is available at the end of the article

\section{Background}

Candida is a polymorphic fungus, it is oval, Gram positive, budding yeast cell that produces pseudohyphae both in culture and in tissues and exudates (Ogaba et al. 2013). Opportunistic fungal infections are a major threat to 
immunocompromised patients (Hawkins and Armstrong 1984). Many factors can compromise the immune system, including low birth weight, cancer, diabetes, AIDS, burns and organ transplantation (Page and Kurtzman 2005). Identification of Candida species causing infections is important for treatment, as not all species respond to the same antimicrobial agent. The ability to detect many different species has become critical as the emergence of non-C. albicans Candida species continues to be increasingly documented (Page and Kurtzman 2005). C. albicans is the most frequently reported species causing human infection, but other species are also reported: including C. glabrata, C. parapsilosis, C. tropicalis and C. krusei, and others (Montes et al. 2019). Phenotypic methods are considered the routine identification of yeast species isolated from clinical samples in many hospitals, through two parts; macroscopic observation including shape, size, colour of colony on agar plate and microscopic observation of fungal structures in the clinical samples and culture and they are still considered the gold standard for identification (Montes et al. 2019). Generally the clinical culture is followed by biochemical based on chromogenic media for identifying the infecting species (Montes et al. 2019). Although these traditional methods are useful, they have some disadvantages, such as the prolonged time they take to generate results until the identification of the microorganism is complete. Moreover, they have limited sensitivity, therefore using nucleic acid-based assays such as PCR allow rapid identification of Candida species (Zhang et al. 2016). Most antifungal medicines used for candidiasis have shown some serious side effects and development of resistance in Candida strains which becomes a serious health concern (Ahmad et al. 2020). In recent research, some alternate antifungal therapy is being tried to make effective treatment options for the treatment of Candidiasis like many metal nanoparticles (NPs) which have been considered in the treatment of Candidiasis and have received significant results concern (Ahmad et al. 2020).

\section{Methods}

\section{Sampling and isolation of fungal elements}

One hundred eighteen samples were collected from private laboratory and private hospitals in Egypt from five sections of immunocompromised patients including 50 diabetic patients, 29 pregnant women, 5 patients underwent organ transplantation (liver And kidney), 19 cancer patients and 15 burned and wounded patients. The collected samples included 59 urine samples, 39 oral swabs, 5 vaginal swabs and 15 skin swabs. All the collected samples were subjected to fungal enrichment by inoculation into Sabouraud dextrose broth (SDB) tubes, then the tubes were incubated at $30{ }^{\circ} \mathrm{C}$ for $24 \mathrm{~h}$ and then examined visually for turbidity.

\section{Phenotypic identification of the isolates}

Turbid SDB tubes suspected to contain fungal elements were identified by morphotyping, macroscopic and microscopic examination according to Montes et al. (2019).

\section{Macroscopic identification}

A loopful taken from every turbid SDB tube was streaked on Sabouraud dextrose agar (SDA, Lot. no 1594522/ Oxoid) with chloramphenicol ( $16 \mathrm{mg} / \mathrm{ml}$, Neo Quimica) (Marinho et al. 2010). Then the plates were incubated at $30{ }^{\circ} \mathrm{C}$ for $48 \mathrm{~h}$. Each grown colony was checked for size, colour and shape.

One single colony grown from each SDA plate was picked up and streaked on CHROMagar (CONDA, Spain) plate, and then, the plates were incubated at $37{ }^{\circ} \mathrm{C}$ for $48 \mathrm{~h}$. Green colonies are interpreted as C. albicans, blue colonies are defined as $C$. tropicalis, and light white to purple colonies are defined as C. glabrata; purple to pink colonies are defined as C. krusei; and pale colonies are referred to $C$. parapsilosis.

\section{Microscopic identification \\ Gram staining}

One single colony from each SDA plate was streaked on a clean glass slide, stained with Gram stain and examined microscopically under oil immersion lens.

\section{Germ-tube test}

One single colony from each SDA plate was picked up and incubated with $0.5 \mathrm{ml}$ human serum in an Eppendorf at $37^{\circ} \mathrm{C}$ for $2-3 \mathrm{~h}$. After incubation, microscopic examination of a loopful from each Eppendorf was carried out (Souza 1998).

\section{Chlamydospores forming test:}

The test was performed using rice extract agar medium (REA) (10 g rice, $10 \mathrm{~g}$ bacteriological agar, and distilled water adjusted to a final volume of $1000 \mathrm{ml}$ ) supplemented with $8 \mathrm{ml}$ of Tween 80 (Montes et al. 2019).

One single colony from SDA plate was streaked (very thinly) on the surface of (REA) plate in 3-4 broad zigzag lines then covered with cover glass and incubated for $9 \mathrm{~h}$ at $22-25{ }^{\circ} \mathrm{C}$ and then the plate was examined microscopically.

\section{Biotyping}

Biochemical identification of the Candida isolates was carried out using API 20C Aux strips. One single colony from young Candida isolate culture taken from SDA 


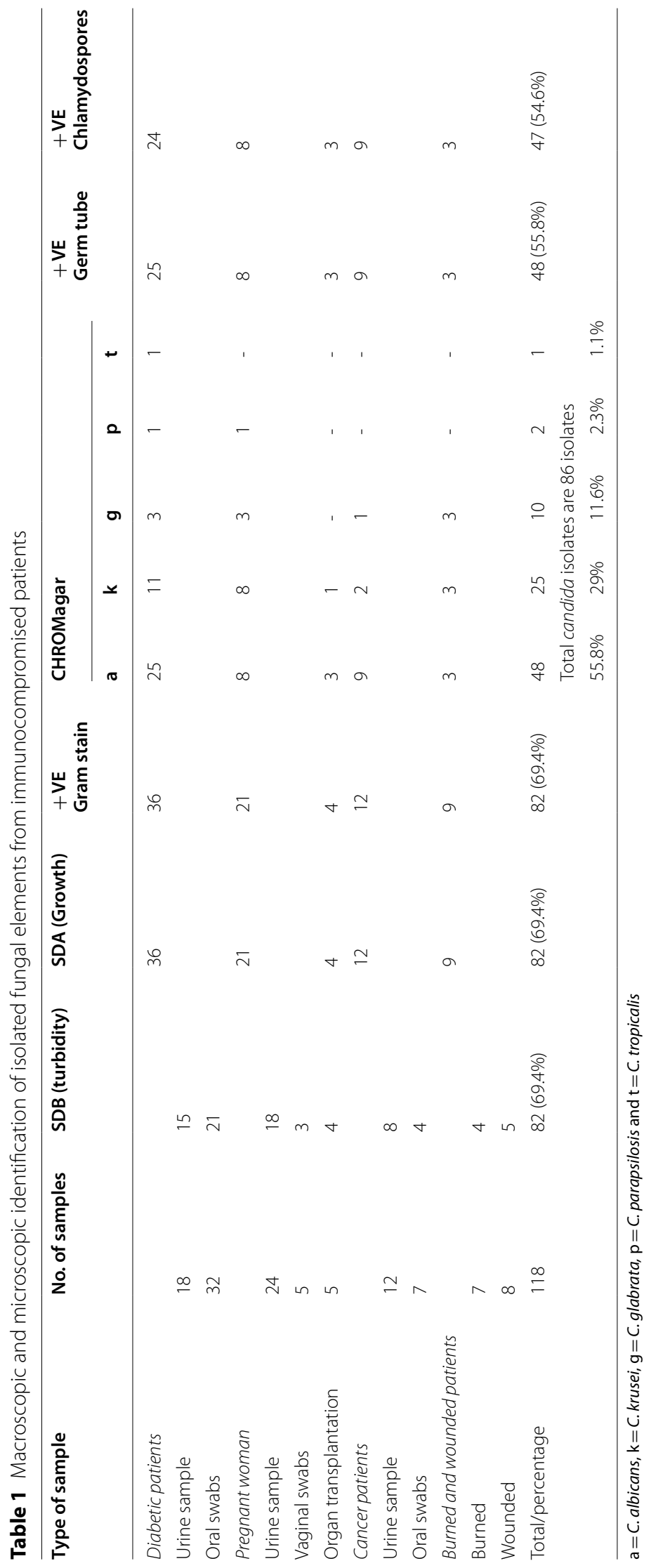




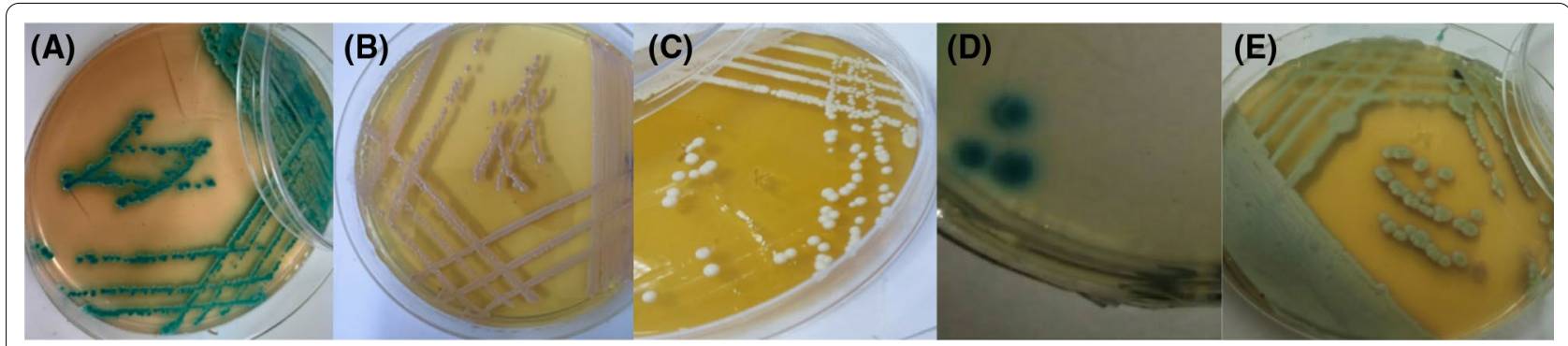

Fig. 1 CHROMagar plates, A C. albicans, B C. krusei, C C. glabrata, D C. tropicalis and E C. parapsilosis

plate was immersed into an API 20C suspension tube, and the degree of turbidity was adjusted equal to $2 \mathrm{Mcfir}-$ land tube. Suspension tube $(100 \mu \mathrm{l})$ was added to API 20 $\mathrm{C}$ medium tube. The cupules of the strip were filled with the suspension from API $20 \mathrm{C}$ medium tube, and then, the strips were incubated at $30{ }^{\circ} \mathrm{C}$ (for 24,48 and $72 \mathrm{~h}$ ). After incubation, the turbidity of cupules was observed and recorded, then a profile number is generated. The obtained figures were subjected to computerized analysis to identify the Candida isolate to species level.

\section{(DNA-based assay; nucleic acid-based assay) genotyping DNA extraction}

DNA extraction of yeast cells was carried out using minipreparation procedure. To a 1.5-ml Eppendorf tube containing $500 \mu \mathrm{l}$ of lysis buffer ( $400 \mathrm{mM}$ Tris- $\mathrm{HCl}$ [pH 8.0], $60 \mathrm{mM}$ EDTA [pH 8.0], $150 \mathrm{mM} \mathrm{NaCl}$ and $1 \%$ sodium dodecyl sulphate), a loopful of yeast colony was added aseptically by using a sterile loop, the tube was then left at room temperature for $10 \mathrm{~min}$. After adding $150 \mu \mathrm{l}$ of potassium acetate, $\mathrm{pH} 4.8(5 \mathrm{M}$ potassium acetate $60 \mathrm{ml}$, glacial acetic acid $11.5 \mathrm{ml}$, distilled water $28.5 \mathrm{ml}$ ), the tube was vortexed briefly and then centrifuged at $>10,000 \mathrm{~g}$ for $1 \mathrm{~min}$ to remove the cellular debris and

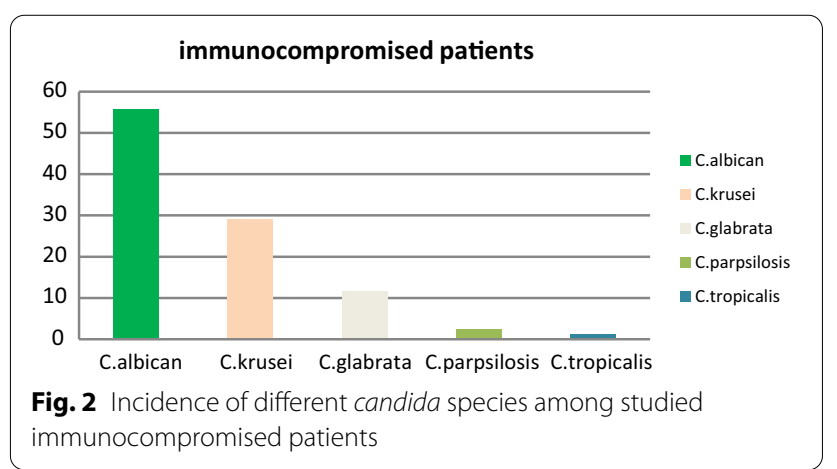

precipitated proteins. The supernatant was transferred to another 1.5-ml Eppendorf tube and centrifuged again as above. After transferring the supernatant to a new 1.5$\mathrm{ml}$ Eppendorf tube, an equal volume of isopropyl alcohol was added. The tube was mixed briefly by inversion, centrifuged at $>10,000 \mathrm{~g}$ for $2 \mathrm{~min}$, and the supernatant was discarded. The resultant DNA pellet was washed in $300 \mu \mathrm{l}$ ethanol $70 \% \mathrm{v} / \mathrm{v}$. After centrifuging at $10,000 \mathrm{~g}$ for $1 \mathrm{~min}$, the supernatant was discarded (Lliu et al. 2002). The DNA pellet was added to EZ-10 Spin Columns (Bio

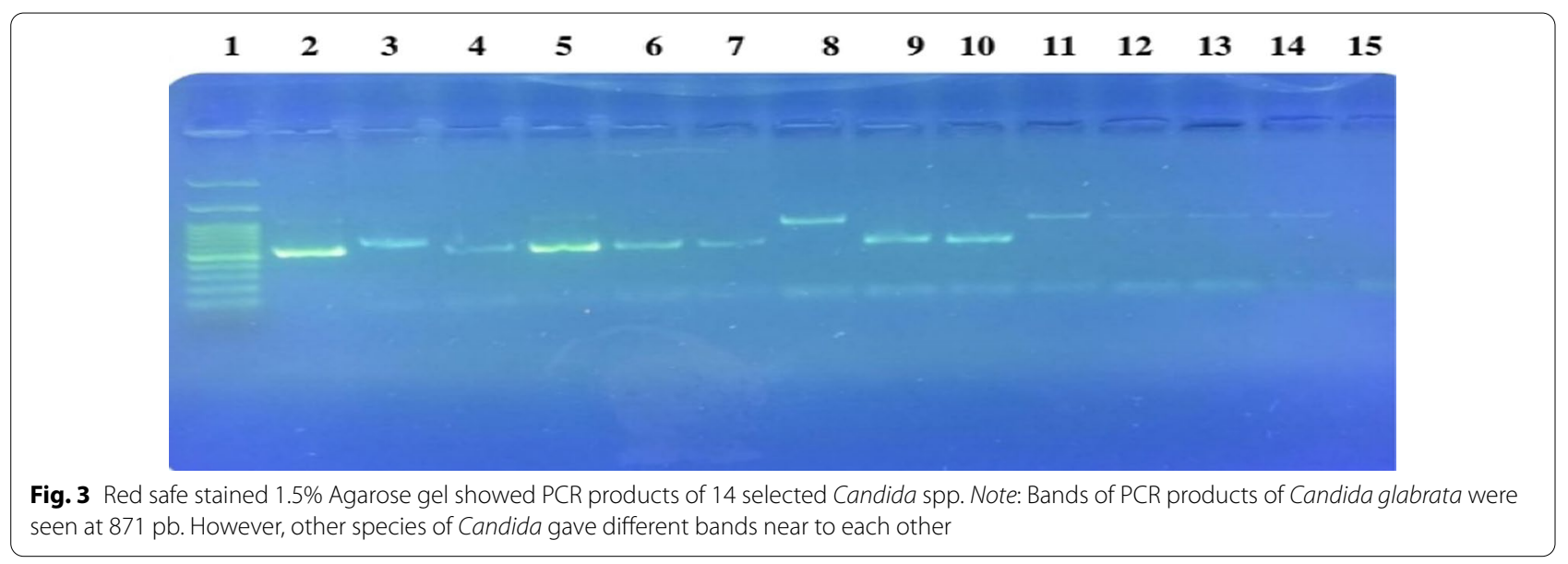


Table 2 API assay of some selected different coloured isolates

\begin{tabular}{|c|c|c|c|c|c|c|}
\hline \multirow[t]{2}{*}{ Tests } & \multicolumn{6}{|c|}{ Colony colour of isolates on CHROMagar } \\
\hline & White colonies & Blue colonies & Green colonies & Rose colonies & Pale colonies & Green colonies \\
\hline 0 & - & - & - & - & - & - \\
\hline D-Glucose & + & + & + & + & + & + \\
\hline Glycerol & - & - & + & - & + & + \\
\hline calcium 2-Keto-Gluconate & - & + & + & - & + & + \\
\hline L-Arabinose & - & - & + & - & + & - \\
\hline D-Xylose & - & + & + & - & + & - \\
\hline ADOnitol & - & + & + & - & + & + \\
\hline XyLiTol & - & - & + & - & - & - \\
\hline D-GALactose & - & + & + & - & + & + \\
\hline INOsitol & - & - & - & - & - & - \\
\hline D-SORbitol & - & + & + & - & + & + \\
\hline Methyl-aD-Glucopyranoside & - & + & + & + & + & - \\
\hline N-Acetyl-Glucosamine & - & + & + & - & + & + \\
\hline D-CELlobiose & - & + & - & - & - & - \\
\hline D-LACtose (bovine origin) & - & - & - & - & - & - \\
\hline D-MALtose & - & + & - & - & + & + \\
\hline $\begin{array}{l}\text { D-SACcha D-SACcharose } \\
\text { (sucrose) rose (sucrose) }\end{array}$ & - & + & + & - & + & + \\
\hline D-TREhalose & + & + & + & - & - & - \\
\hline D-TREhalose & - & + & - & - & + & - \\
\hline D-RAFfinose & - & - & - & - & - & - \\
\hline Identification & C. glabrata & C. tropicalis & C. albicans & C. krusei & C. parapsilosis & C. dubliniensis \\
\hline
\end{tabular}

+ , positive test; - , negative test

Basic Inc.) and centrifuged at $>10,000 \mathrm{~g}$ for $10 \mathrm{~min}$. DNA was eluted in $50 \mu \mathrm{l}$ of $1 \mathrm{X}$ TE buffer and stored at $-20^{\circ} \mathrm{C}$.

\section{PCR amplification}

The PCR was used to amplify intergenic spacer regions; intertranscribed spacer (ITS) of gene encoding $5.8 \mathrm{~S}$ rDNA with primers ITS1 (5'-TCC GTA GGT GAA CCT GCG G-3') and ITS4 (5'-TCC TCC GCT TAT TGA TAT GC-3') (Willowfort.co.UK.). A reaction volume of $50 \mu \mathrm{l}$ contained $25 \mu \mathrm{l}$ master mix PCR [0.16 mM each deoxyribonucleoside triphosphate, $5 \mu \mathrm{l}$ Taq DNA polymerase buffer, $2.5 \mathrm{U}$ Taq DNA-dependent DNA polymerase (intron master mix (i-Taq $\left.{ }^{\mathrm{TM}}\right)$ ), $0.2 \mu \mathrm{M}$ each primer and $1 \mu \mathrm{g}$ genomic DNA as a template. Reaction mixtures were subjected to initial denaturation at $95^{\circ} \mathrm{C}$ for $3 \mathrm{~min}$, followed by 35 cycles of denaturation at $95^{\circ} \mathrm{C}$ for $1 \mathrm{~min}$, primer annealing at $50{ }^{\circ} \mathrm{C}$ for $1 \mathrm{~min}$ and elongation for 2 min at $72{ }^{\circ} \mathrm{C}$. Final extension step was performed at $72{ }^{\circ} \mathrm{C}$ for $10 \mathrm{~min}$. Negative control was carried out using sterile deionized water instead of template DNA. Red safe stained agarose gel (1.5\%) was prepared in $1 \mathrm{X}$ TBE buffer

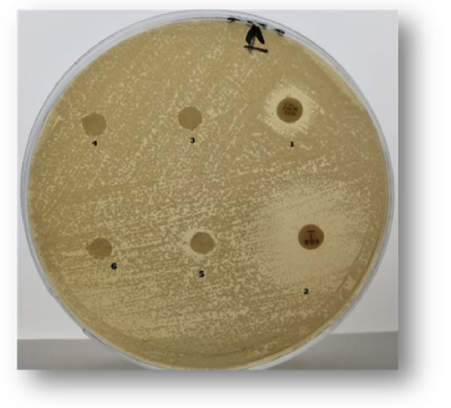

(1)Nystatin,(2)Voriconazole,(3) ZnONPs 25ug/disc,

(4) ZnONPs 50ug/disc,(5) ZnO-NPs 100ug/disc and (6) negative control.

Fig. 4 Antifungal activity of zinc oxide nanoparticles along with nystatin and Voriconazole

(Tris base/boric acid/EDTA). Agarose gel electrophoresis was run at $100 \mathrm{~V}$ and the resulting bands were visualized by UV illumination. PCR products were stored at $-20^{\circ} \mathrm{C}$ until used (Elena et al. 2015). 
Table 3 Antifungal activity (expressed by inhibitory zone) of different concentrations of ZnONPs in comparison with some commercially available antifungals (Nystatin and Voriconazole) against different Candida species

\begin{tabular}{|c|c|c|c|c|c|c|}
\hline \multirow[t]{3}{*}{ Candida spp. } & \multicolumn{6}{|c|}{ Inhibition zone (mm) } \\
\hline & \multicolumn{3}{|c|}{ Concentrations of (ZnONPs) $\mu \mathrm{g} / \mathrm{disc}$} & \multirow[t]{2}{*}{ Nystatin (100 unit/disc) } & \multirow[t]{2}{*}{ Voriconazole ( $1 \mu \mathrm{g} / \mathrm{disc})$} & \multirow{2}{*}{$\begin{array}{l}\text { Negative } \\
\text { control }\end{array}$} \\
\hline & 25 & 50 & 100 & & & \\
\hline C. albicans & 0 & 0 & 40 & 10 & 44 & 0 \\
\hline C. tropicalis & 0 & 0 & 9 & 11 & 22 & 0 \\
\hline C. glabrata & 0 & 0 & 26 & 20 & 52 & 0 \\
\hline C. krusei & 0 & 0 & 0 & 12 & 40 & 0 \\
\hline C. parapsilosis & 0 & 7 & 42 & 13 & 0 & 0 \\
\hline
\end{tabular}

\section{Antifungal activity of zinc oxide nanoparticles and commercial antibiotics against Candida isolates}

Two commercially available antifungals (nystatin 100 unite/disc-Oxoid) and (Voriconazole $1 \mu \mathrm{g} /$ disc-Oxoid) and zinc oxide nanoparticles (ZnONPs) used in this study are chemically synthesized and taken from Mona Mohammed Hassan a researcher at national Research Center.

Candida species selected for this test were cultivated on SDA and incubated at $37^{\circ} \mathrm{C}$ for $24 \mathrm{~h}$ and a yeast suspension in distilled water equal to $1 / 2 \mathrm{McF}$ arland was done.

A colloidal solution from $10 \mathrm{mg}$ of $\mathrm{ZnONPs}$ dissolved in $500 \mu \mathrm{l}$ distilled water was performed using a sonicator for $5 \mathrm{~min}$. Three different ZnONPs concentrations (25$50-100 \mu \mathrm{g} /$ disc) were prepared and the yeast suspension was spread on the SDA plate then the discs loaded by ZnONPs were distributed on the plate. The plates were incubated at $37{ }^{\circ} \mathrm{C}$ for $48 \mathrm{~h}$. The inhibitory zone (s) was measured after the incubation period and recorded.

\section{Results}

\section{Macroscopic and microscopic identification}

Out of 118 collected samples inoculated into SDB tubes, 82 revealed turbidity and thus denoted fungal growth. The absence of turbidity in the rest of collected samples showed no fungal elements in these samples. Eightytwo SDA plates separately streaked with loopfuls from 82 SDB turbid tubes showed macroscopically creamy, opaque, smooth and white colonies of different sizes suspected to be Candida spp. (Table 1).

Microscopic examination of Gram stained cultures obtained from 82 samples showed Gram positive (purple), round or ovoid appeared cells with or without budding (Table 1).

Visual examination of culture inoculated CHROMagar plates showed 86 different isolates according to their colours (Fig. 1).
Four more isolates resulted from using CHROMagar plates showed the presence of mixed colonies in some samples.

Out of 86 isolates, 48 showed positive germ tube test which was characterized by microscopic slender tubes erupted from the Candida cells each with straight walls, without septum and constriction at the junction between the cells positive germ tube test is found only with $C$. albicans and C. dubliniensis (Table 1).

Out of 86 isolates, 47 gave positive Chlamydospores forming test (C. albicans) which was characterized microscopic revealed refractile cell wall with double contours. The rest 48th isolate was non-albicans candida (Table 1).

\section{API 20 C AUX}

Upon carrying out API 20C AUX assay on few selected isolates (according to coloured colonies grown on CHROMagar), 9 out of 10 isolates with green coloured colonies revealed Candida albicans $(77.8-96.7 \%)$ when tested with API 20C. The tenth isolate appeared to be Candida dubliniensis (99\%). Nine isolates showing rose colonies on CHROMagar and subjected to API assay revealed the existence of Candida krusei (98.9\%). Four isolates showing white colour on CHROMagar and subjected to API assay revealed the existence of Candida glabrata (91.5-99\%). One isolate with blue coloured colonies revealed Candida tropicalis (88.9\%). Two isolates with pale coloured colonies revealed Candida parapsilosis (99.9\%) (Table 2 and Fig. 2).

\section{PCR amplification}

PCR assay was applied on 14 selected samples from different coloured colonies. Samples no. 1, 2 and 3 gave a band at $535 \mathrm{pb}$ specific to C. albicans. Sample no 4 gave a band at 524 bp specific to C. tropicalis. Samples no. 5, 6 and 7 gave a band at 510 bp specific to C. krusei. Samples 
no 8 and 9 gave bands at 520 pb specific to C. parapsilosis samples no. 10,11,12 and 13 gave bands at 871 pb specific to C. glabrata and sample no 14 is negative sample with no band appeared (Fig. 3).

\section{Antifungal activity}

The antifungal activity $\mathrm{ZnONPs}$ were evaluated against 5 Candida spp. The obtained results showed that discs loaded by low concentrations 25 and $50 \mathrm{ppm}$ not affect the all Candida spp. except $C$. parapsilosis that inhibited at $50 \mathrm{ppm}$ with $7 \mathrm{~mm}$ inhibition zone (Fig. 4), while all Candida spp. were sensitive to $100 \mathrm{ppm}$ of ZnONPs except C. krusei. C. parapsilosis was highly inhibited (42 $\mathrm{mm}$ inhibition zone), followed by $C$. albicans, followed by C. glabrata. Antifungal activities of $\mathrm{ZnO}$ NPs and their mode of action were investigated previously (Lili et al. 2011; Arciniegas-Grijalba et al. 2019). ZnONPs remarkably reduced the germ tube formation of C. albicans (Jalal et al. 2018). Recently ZnONPs showed antifungal activity against pathogenic Candida spp. with minimum inhibitory concentration (MIC) and minimum fungicidal concentration (MFC) ranges against Candida spp. was $256-512 \mu \mathrm{g} / \mathrm{ml}$, respectively (Kermani et al. 2021).

In the (Table 3) the best concentration effect of zinc oxide nanoparticles alone on Candida species was $100 \mu \mathrm{g} /$ disc.

\section{Discussion}

Rapid and accurate identification of Candida species down to the species level is of great importance for the selection of appropriate antifungal agents and for patient management. In the present study, 118 different samples gave 82 Candida isolates on SDB and SDA, while the grown isolates on CHROMagar were 86 isolates. This is due to the presence of mixed Candida infection (the presence of more than one different isolate in the same sample). Five Common Candida Species were found among the present isolates; however, Candida albicans was the most frequently isolated yeast in the present study, its prevalence was lower than a study conducted in Northwest Ethiopia (Mulu et al. 2013) and higher than a study conducted in central Ethiopia (Bitew and Abebaw 2018).

In the Middle East and North Africa, a study demonstrated shift of Candida albicans towards non-albicans Candida species. In the present study, C. krusei was the second predominant species. Our result was similar to that of Bitew and Abebaw (2018), but in contradiction with many other studies where C. glabrata or C. tropicalis was reported as a second predominant non-albicans species (Mulu et al. 2013).

API biochemical assay results were similar to those of CHROMagar except for $C$. dubliniensis on CHROMagar appeared green colour such as C. albicans but gave positive germ tube and not Chlamydospores former.

Understanding the local epidemiology of Candida is of great relevance for the clinical management of candidiasis. Therefore, it is essential to detect the diversity of Candida, including phenotypic and genotypic features of these pathogens (Cornet et al. 2011). PCR-based approaches can be used to local epidemiological investigation of Candida species (Małek et al. 2017a, b).

To reduce these Candida, commercial antifungals were used, $\mathrm{ZnONPs}$ and these $\mathrm{ZnONPs}$ were used to reduce the resistance of some types of candida to commercial antifungals, nanoparticles showed an effect on Candida, according to Jalal et al. (2018).

\section{Conclusions}

A sheet of identification profile for Candida should include morphotyping, biotyping and genotyping to reach a rapid, reliable and accurate diagnosis. Candida species causes a myriad of infections causing non-invasive, mucocutaneous infections and severe systemic and deep-seated disease. Repress of Candida growth by ZnONPs provides an insight towards their therapeutic application for the prevention of Candidaassociated infections. Further studies on the antifungal effect of nanoparticles combined with commercially available antifungal medicines maybe recommended.

\section{Abbreviations \\ SDB: Sabouraud Dextrose Broth; SDA: Sabouraud Dextrose Agar; REA: Rice Extract Agar; PCR: Polymerase Chain Reaction; DNA: Deoxyribonucleic acid; EDTA: Ethylene diamine tetra acetic acid; API: Analytical Profile Index; NS: Nystatin; VOR: Voriconazole; ZnONPs: Zinc Oxide Nanoparticles.}

\section{Acknowledgements}

We thank Prof. Dr. Muhammad Rushdy, professor at the Faculty of Science, AlAzhar University, for contributing to the design of the research protocol and we thank Dr. Mona Mohamed Hassan, a researcher in the Microbiology and Immunology department at the National Research Center, for providing some materials to complete the research.

\section{Authors' contributions}

TM, MM and AS conceived and designed the study. AS and MM carried out most of the laboratory work. AS, TM and MM analysed and interpreted the data. AS, MM and TM helped in writing —original draft. All authors read and approved the final manuscript.

Funding

No found was available.

Availability of data and materials

All the data included in the current study are available.

\section{Declarations}

Ethics approval and consent to participate

The study protocol was approved by the Ethics Committee of the National Research Center, Cairo, Egypt under number (72117082021). 


\section{Consent for publication}

Not applicable.

\section{Competing interests}

The authors have no conflict of interest to declare.

\section{Author details}

${ }^{1}$ Botany and Microbiology, Faculty of Science, Al-Azhar University, Cairo, Egypt. ${ }^{2}$ Microbiology and Immunology Department, National Research Center, Dokki, Giza, Egypt.

Received: 27 June 2021 Accepted: 29 August 2021

Published online: 30 September 2021

\section{References}

Ahmad N, Jafri Z, Khan ZH (2020) Evaluation of nanomaterials to prevent oral Candidiasis in PMMA based denture wearing patients. A systematic analysis. J Oral Biol Cranio Fac Res 10(2):189-193. https://doi.org/10. 1016/j.jobcr.2020.04.012

Arciniegas-Grijalba PA, Patiño-Portela MC, Mosquera-Sánchez LP, Guerra Sierra BE, Muñoz-Florez JE, Erazo-Castillo LA, Rodríguez-Páez JE (2019) ZnObased nanofungicides: synthesis, characterization and their effect on the coffee fungi Mycena citricolor and Colletotrichum sp. Mater Sci Eng C Mater Biol Appl 98:808-825. https://doi.org/10.1016/j.msec.2019.01.031

Bitew A, Abebaw Y (2018) Vulvovaginal candidiasis: species distribution of Candida and their antifungal susceptibility pattern. BMC Womens Health 18:94. https://doi.org/10.1186/s12905-018-0607-z

Cornet M, Sendid B, Fradin C, Gaillardin C, Poulain D, Nguyen HV (2011) Molecular identification of closely related Candida species using two ribosomal intergenic spacer fingerprinting methods. J Mol Diagn 13:12-22

Elena R, Simona ES, Diana P, Ionela S, Cojocaru M, Tatiana V (2015) Identification of species of the genus Candida by analysis of 5.8S rRNA gene. Roman Biotechnol Lett 20:4

Hawkins C, Armstrong D (1984) Fungal infections in the immunocompromised host. Clin Haematol 13:599-630

Jalal M, Ansari MA, Ali SG, Khan HM, Rehman S (2018) Anticandidal activity of bioinspired ZnO NPs: effect on growth, cell morphology and key virulence attributes of Candida species. Artif Cells Nanomed Biotechnol Int J 46(1):912-925. https://doi.org/10.1080/21691401.2018.1439837

Kermani SA, Salari S, Almani PG (2021) Comparison of antifungal and cytotoxicity activities of titanium dioxide and zinc oxide nanoparticles with amphotericin B against different Candida species: In vitro evaluation. J Clin Lab Anal 35(1):e23577. https://doi.org/10.1002/jcla.23577

Lili H, Liu Y, Lin AMM (2011) Antifungal activity of zinc oxide nanoparticles against Botrytis cinerea and Penicillium expansum. Microbiol Res 166(3):207-215

Lliu D, Pearce L, Lilley G, Coloe S, Baird R, Pedersen J (2002) PCR identification of dermatophyte fungi Trichophyton rubrum. J Med Microbiol 51(2):117-122

Małek M, Paluchowska P, Bogusz B, Budak A (2017a) Molecular characterization of Candida isolates from intensive care unit patients, Krakow, Poland. Rev Iberoam Micol 34(1):10-16. https://doi.org/10.1016/j.riam.2016.03.005

Małek M, Paluchowsk P, Bogusz B, Budak A (2017b) Molecular characterization of Candida isolates from intensive care unit patients, Krakow, Poland. Rev Iberoam Micol 34:1. https://doi.org/10.1016/j.riam.2016.03.005

Marinho SA, Teixeira AB, Santos OS, Cazanova RF, Ferreira CA, Cherubini K, de Oliveira SD (2010) Identification of Candida spp. by phenotypic tests and PCR. Braz J Microbiol 41(2):286-294. https://doi.org/10.1590/S1517-83822 010000200004

Montes K, Ortiz B, Galindo C, Figueroa I, Braham S, Fontecha G (2019) Identification of Candida species from clinical samples in a Honduran Tertiary Hospital. Pathogens 8(4):237. https://doi.org/10.3390/pathogens8040237

Mulu A, Kassu A, Anagaw B, Moges B, Gelaw A, Alemayehu M et al (2013) Frequent detection of 'azole' resistant Candida species among late presenting AIDS patients in northwest Ethiopia. BMC Infect Dis 13:82

Ogaba OM, Abia-Bassy LN, Epoke J, Mandor BI, Iwatt GD (2013) Characterization of Candida species isolated from cases of lower respiratory tract infection among HIV/AIDS patients in Calabar, Nigeria. World J AIDS 3:201-206

Page BT, Kurtzman CP (2005) Rapid identification of Candida species and other clinically important yeast species by flow cytometry. J Clin Microbiol 43(9):4507-4514

Souza VM (1998) Técnicas laboratoriais utilizadas em micologia médica. In: Zaitz C, Campbell I, Marques AS, Ruiz LR, Souza VM (eds) Compêndio de micologia médica. Medsi, Rio de Janeiro, pp 51-63

Zhang J, Hung GC, Nagamine K, Li B, Tsai S, Lo SC (2016) Development of Candida-specific real-time PCR assays for the detection and identification of eight medically important Candida species. Microb Insights 9(21):28

\section{Publisher's Note}

Springer Nature remains neutral with regard to jurisdictional claims in published maps and institutional affiliations.

\section{Submit your manuscript to a SpringerOpen ${ }^{\circ}$ journal and benefit from:}

- Convenient online submission

- Rigorous peer review

- Open access: articles freely available online

- High visibility within the field

- Retaining the copyright to your article

Submit your next manuscript at springeropen.com 